\title{
Introduction of the best criterion for evaluation of tolerance to drought stress in sorghum's genotypes
}

\author{
Leyla NAZARI ${ }^{1,2}$, Ebrahim DEHGHANIAN ${ }^{3}$, Afshar ESTAKHR ${ }^{1}$, Azim KHAZAEI ${ }^{4}$, Behzad SORKH- \\ ILALEHLOO $^{4}$, Mohammad Reza ABBASI ${ }^{5}$
}

Received April 15, 2021; accepted December 09, 2021.

Delo je prispelo 15. aprila 2021, sprejeto 9. decembra 2021

\begin{abstract}
Introduction of the best criterion for evaluation of tolerance to drought stress in sorghum's genotypes

Abstract: Sorghum (Sorghum bicolor (L.) Moench) is the fifth important cereal considered a drought-tolerant crop. However, its reduction of grain yield considerably occurs in a shortage of water. In the current study, 10 sorghum genotypes were assessed for their grain yield under normal irrigation and water deficit irrigation. As well, the efficacy of several drought indices was evaluated for the selection of high-yield and drought-tolerant genotypes. The experiment was conducted as a split-plot considering three irrigation levels as main-plot and 10 genotypes as sub-plot. Correlation among the indices, clustering of the genotypes along with principal component analysis was employed. Yield production was significantly and positively correlated with indices MP (mean productivity), STI (stress tolerance index), GMP (geometric productivity), HM (harmonic mean), and YI (yield index) in all the irrigation levels. Therefore, these indices are more effective in the selection of high-yielding genotypes under different water conditions. Rank means of stress indices for each genotype revealed that genotype TN-04-79 in mild deficit irrigation and genotypes KGS23 and TN-04-79 in severe deficit irrigation were the most tolerant.
\end{abstract}

Key words: sorgum; drought stress; grain yield; water productivity; drought response indices

\section{Uvajanje najboljših kriterijev za ovrednotenje tolerance na sušo pri genotipih sirka}

Izvleček: Navadni sirek (Sorghum bicolor (L.) Moench) je peto najpomembnejše na sušo odporno žito, a se kljub temu njegov pridelek zrnja znantno zmanjša ob pomanjkanju vode. $\mathrm{V}$ tej raziskavi je bilo ocenjenih 10 genotipov navadnega sirka glede na pridelek zrnja ob normalnem namakanju in v razmerah vodnega deficita. Ocenjeni so bili tudi različni indeksi tolerance na sušo pri izboru genotipov z velikimi pridelki zrnja in dobre tolerance na sušo. Poskus je bil izveden kot puskus z deljenkami, kjer so bila obravnavanja $\mathrm{z}$ namakanjem na glavnih ploskvah in 10 genotipov na podploskvah. Uporabljene so bile korelacije med indeksi in združevanje genotipov glede na glavno komponento. Velikost pridelka je bila značilno pozitivno povezana $\mathrm{z}$ indeksi MP (poprečna produktivnost), STI (indeks tolerance na stres), GMP (geometrična produktivnost), HM (harmonično poprečje) in YI (indeks pridelka) pri vseh načinih namakanja. Ti indeksi so torej bolj učinkoviti pri izboru visoko donosnih genotipov v razmerah različne preskrbe $\mathrm{z}$ vodo. Poprečje rangov stresnih indeksov za vsak genotip je odkrilo, da je genotip TN-04-79 najučinkoviteši ob blagem pomanjkanju vode, genotipa KGS23 in TN-04-79 pa sta bila najbolj odporna na sušo.

Ključne besede: navadni sirek; sušni stres; pridelek zrnja; učinkovitost izrabe vode; indeksi odziva na sušni stres

1 Crop and Horticultural Science Research Department, Fars Agricultural and Natural Resources Research and Education Center, Agricultural Research, Education and Extension Organization (AREEO), Shiraz, Iran

2 Corresponding author, e-mail: 1.nazari@areeo.ac.ir

3 Agricultural Engineering Research Department, Fars Agricultural and Natural Resources Research and Education Center, Agricultural Research, Education and Extension Organization (AREEO), Shiraz, Iran

4 Seed and Plant Improvement Institute, Agricultural Research, Education and Extension Organization (AREEO), Karaj, Iran

5 Crop and Horticultural Science Research Department, Khorasan Razavi Agricultural and Natural Resources Research and Education Center, Agricultural Research, Education and Extension Organization (AREEO), Mashhad, Iran 


\section{INTRODUCTION}

Sorghum (Sorghum bicolor (L.) Moench) is a $\mathrm{C}_{4}$ and drought-tolerant crop used for food, feed, and fiber (Ludlow et al., 1990). Its tolerance to drought can be attributed to morphological characteristics (e.g. deep root system and thick leaf wax), physiological responses (e.g. stay green and osmotic adjustment), and adaptive mechanisms allowing tolerance under extreme drought conditions (reviewed in Tari et al., 2013). In the dry region of Asia and the Middle East, drought is one of the most important abiotic stresses, leading to the limitation of plant growth and yield productivity (Zhang et al., 2018). Therefore, improving yield production per unit of water (water productivity) is an efficient strategy in dry regions (Ali and Talukder, 2008).

Blum (2005) suggested that the selection of genotypes should mainly focus on high yield under non-stress conditions and secondly under water stress conditions. The selection of genotypes that have tolerant genes is difficult as drought tolerance is a quantitative trait with intricate heritability. Therefore, despite the lack of information on drought tolerance mechanisms, researchers have proposed the utility of different selection indices to screen drought-tolerant genotypes (Anwaar et al., 2019). Hence, we have employed the following selection criteria for screening drought-tolerant genotypes and introducing the best indices.

Several indices based on the yield under control $\left(Y_{p}\right)$ and stress $\left(\mathrm{Y}_{\mathrm{s}}\right)$ have been introduced for the selection of drought-tolerant genotypes. Among these, the indices employed in various stress conditions are stress tolerance (TOL) and mean productivity (MP) introduced by Rosielle and Hamblin (1981), Stress susceptibility index (SSI) by (Fischer and Maurer, 1978), stress tolerance index (STI) and geometric mean productivity (GMP) by Fernandez (1992), Harmonic mean of yield (HM) by Jafari et al. (2009), yield index (YI) by Gavuzzi et al. (1997), yield stability index (YSI) by Bouslama and Schapaugh (1984), yield reduction ratio (YRR) by Golestani-Araghi and Assad (1998). Selection of high-yield genotypes in both normal and deficit irrigation using a combination of these indices is preferred. Therefore, different statistical analyses including analysis of variance (ANOVA), corre- lation, principal component analysis (PCA), and cluster analysis were performed. The study aimed to investigate the efficiency of the mentioned indices for screening tolerant genotypes of sorghum to drought stress.

\section{MATERIALS AND METHODS}

\subsection{EXPERIMENTAL SITE}

The experiment was conducted at the Research Farm of Fars Agricultural and Natural Resources Research and Education Center, Shiraz, Iran ( $52^{\circ} 42^{\prime}$ E, $29^{\circ} 46^{\prime}$ N, 1.604 $\mathrm{m}$ elevation) with a semi-arid environment (Fig. 1a). It is characterized by mean annual precipitation of $345 \mathrm{~mm}$
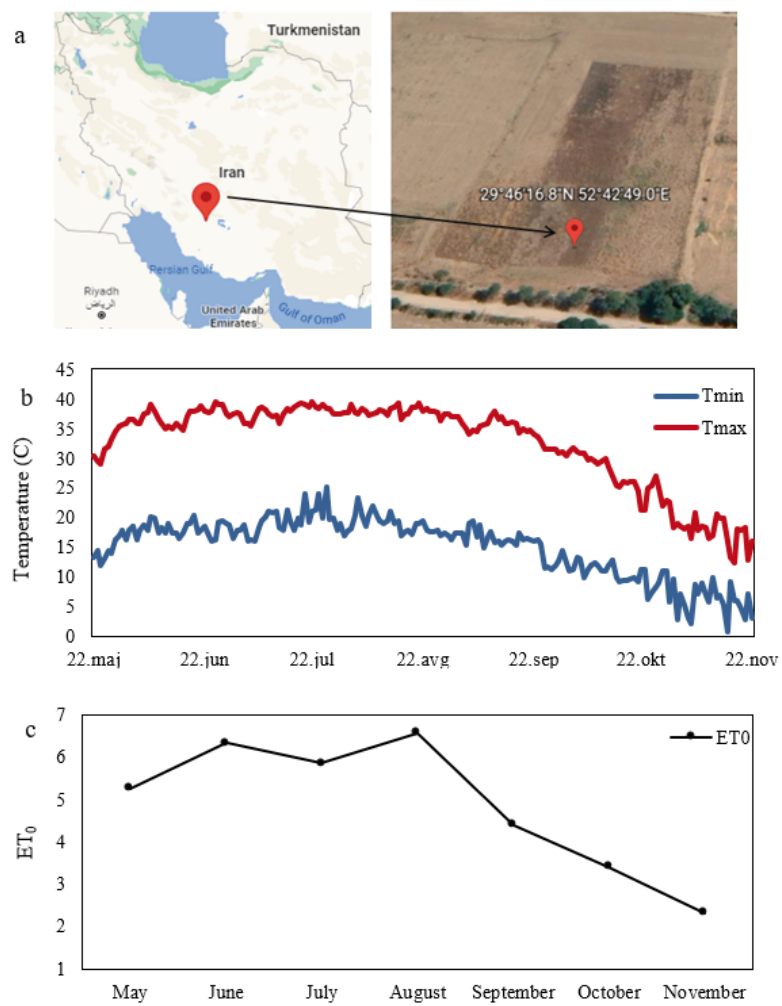

Fig. 1: The spatial position of the experimental site captured on 07/11/2021 (a); minimum and maximum of temperature (b) and $\mathrm{ET}_{0}$ (c) during the growth season (2018) conducted at Zargan, Iran $\left(52^{\circ} 42^{\prime} \mathrm{E}, 29^{\circ} 46^{\prime} \mathrm{N}\right)$

Table 1: The chemical properties of the soil in the experimental area

\begin{tabular}{llllllllllll}
\hline $\begin{array}{l}\text { soil depths } \\
\mathrm{cm}\end{array}$ & $\mathrm{pH}$ & $\mathrm{EC}^{\star} 10^{3}$ & O.C $\%$ & $\begin{array}{l}\text { phosphorus } \\
\mathrm{ppm}\end{array}$ & $\begin{array}{l}\text { potassium } \\
\mathrm{ppm}\end{array}$ & sand \% & silt \% & clay \% & $\begin{array}{l}\text { zinc } \\
\mathrm{ppm}\end{array}$ & $\begin{array}{l}\text { magnesium } \\
\mathrm{ppm}\end{array}$ & $\begin{array}{l}\text { copper } \\
\mathrm{ppm}\end{array}$ \\
\hline $0-30$ & 8.0 & 0.97 & 0.95 & 11.2 & 434 & 20.4 & 46.2 & 33.4 & 0.80 & 7.60 & 0.90 \\
$30-60$ & 7.9 & 2.15 & 0.81 & 4.2 & 310 & 20.4 & 42.8 & 36.8 & 0.96 & 8.50 & 0.96 \\
\hline
\end{tabular}

EC: electrical conductivity; O.C: organic carbon; extractable phosphorus was measured according to Olson method 
and an annual temperature of $15.8^{\circ} \mathrm{C}$. Minimum and maximum temperature and $\mathrm{ET}_{0}$ during growth season are presented in Fig. 1b,c. The soil is characterized by fine, carbonatic, active, thermic Typic Calcixerepts (soil taxonomy, 2014) and Cambic Calcisol (Lomic, Ochric) (WRB, 2015). The fertilizers were distributed based on soil test results (Table 1).

\subsection{EXPERIMENTAL DESIGN}

The plants (10 sorghum genotypes, supplementary Table 1) were cultivated manually as split-plot in a randomized complete block design with three replicates on 6 June 2018. Water deficit treatment was considered as the main factor and genotype as the sub-factor. Subplots were $12 \mathrm{~m}^{2}$ including 4 rows of $5 \mathrm{~m}$ long with a row distance of $0.6 \mathrm{~m}$. Tinning was performed 4 weeks after sowing with a target of 10 plants per linear meter. Weed control was performed manually during the season.

Irrigation treatments were applied to the main plots at three levels of normal irrigation, mild and severe water-deficit irrigation defined as irrigation when the evaporation rates from pan class A exceeded 60, 120, and $180 \mathrm{~mm}$, respectively. Water stress was started from the 5 leaves stage and continued during the season.

Irrigation was applied using a tape drip and the irrigation volume was recorded by using a volumetric counter. FAO-CROPWAT 8.0 as a decision support system (DSS) was used to calculate the reference crop evapotranspiration (ETo) (Clarke, 2001) and schedule different levels of irrigation. The accuracy of this method was demonstrated by comparing it to original crop water requirements (Surendran et al., 2019). Meteorological data were taken daily from the Zargan Meteorological Station near the experimental field. The irrigation requirement was calculated according to Doorenbos and Pruitt (1977) (Table 2).

\subsection{MEASUREMENTS AND DROUGHT INDICES}

Agronomic characteristics including plant height $(\mathrm{PH})$, panicle length $(\mathrm{PL})$, stem diameter $(\mathrm{SD})$, and the number of leaves per plant (NoL) were recorded for 10 plants per plot from the middle two-row of each plot. As well, 1000 seed mass (1000 SM), dry matter yield (DMY), and harvest index (HI) were recorded. Water productivity (WP) was calculated as Ali and Talukder (2008) (Table 2).

Drought tolerance indices were calculated according to the equations in Table 2. Ranking of the genotypes

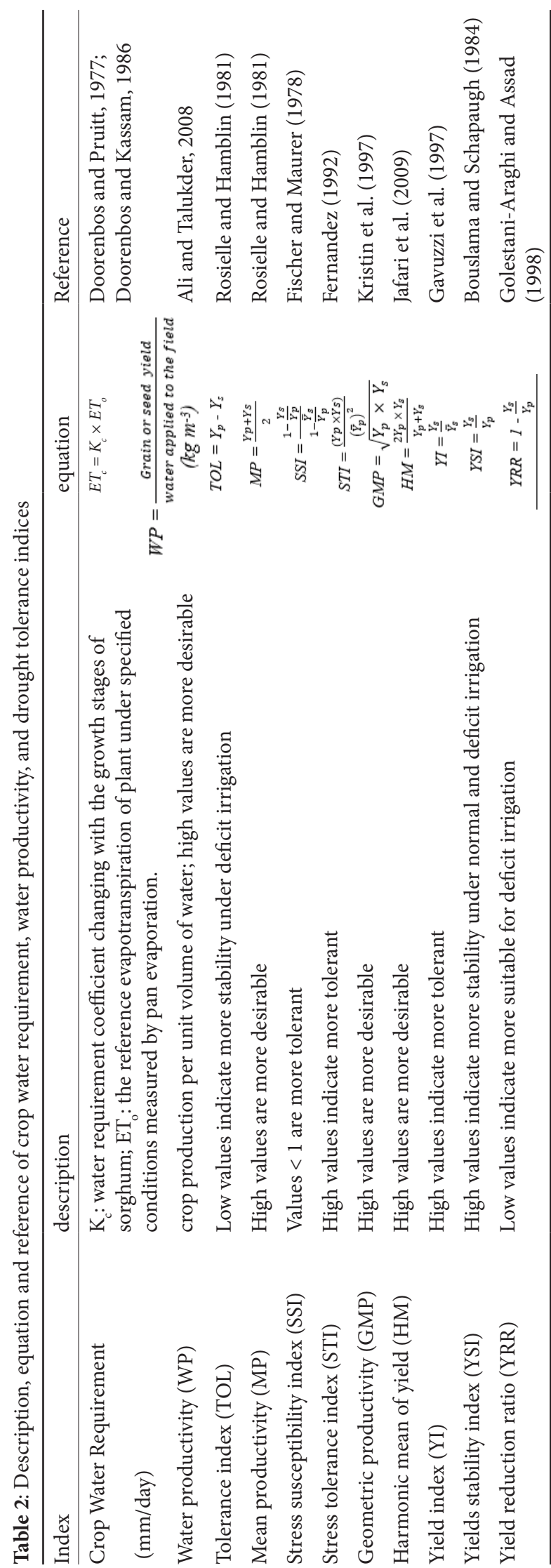

Acta agriculturae Slovenica, 117/4 - 2021 
based on the indices was performed according to the method of Mickky et al. (2019).

The means of grain yield and the indices were ranked considering that indices with higher values are more desirable except TOL, SSI, and YRR. Afterward, rank mean $\left(\mathrm{R}^{\prime}\right)$ and standard deviation of rank (SDR) were calculated. Rank mean is defined as the average of ranking values across all drought tolerance indices of each genotype. Rank sum (RS) of each genotype was then determined by the addition of rank mean (R') and standard deviation of rank (SDR).

\subsection{STATISTICAL ANALYSIS}

Analysis of variance (ANOVA) and mean comparison were performed using SAS release 9.2 (SAS Institute, Cary, NC, USA). Before doing ANOVA, normality tests were conducted. Provided that $F$-values were significant, a mean comparison was done (Duncan's test, $p \leq 0.05$ ). Drought stress indices, principal component analysis (PCA) and Pearson's correlation between the indices were performed using iPASTIC that is an online tool kit for the estimation of plant abiotic stress indices (Khalili et al., 2016). Genotypes were clustered using Ward's hierarchical clustering.

\section{RESULTS AND DISCUSSION}

Here, we evaluated 10 sorghum genotypes for drought tolerance collected from different parts of Iran and kept at The National Plant Gene-Bank of Iran, SPII. Natural genetic diversity may play an important role in food security through pre-breeding programs or the introduction of important traits or genes into existing cultivars (Priyanka et al., 2021). As well, the efficacy of drought stress indices for screening of these genotypes was scrutinized. Using the yield values of $Y_{p}$ and $Y_{s}$, various indices were calculated (Table 4) and the genotypes were ranked for each index (Table 5).

\subsection{MORPHOLOGICAL TRAITS}

Significant differences were observed between irrigation regimes for all traits $(p<0.01$ for $\mathrm{PH}, \mathrm{SD}$, and DMY; $p<0.05$ for PL and 1000 SM) except NoL. There were significant differences between genotypes for all traits $(p<0.01)$ indicating significant variation among the genotypes. The interaction effect of deficit irrigation $\times$ genotype was significant $(p<0.01)$ except for NoL and 1000 SM.

Table 3: The main effects of irrigation level and genotype on morphological traits, yield, and water productivity of 10 sorghum genotypes

\begin{tabular}{|c|c|c|c|c|c|c|c|c|c|}
\hline Treatments & $\begin{array}{l}\mathrm{PH} \\
\mathrm{cm}\end{array}$ & $\begin{array}{l}\mathrm{PL} \\
\mathrm{cm}\end{array}$ & $\begin{array}{l}\mathrm{SD} \\
\mathrm{mm}\end{array}$ & NoL & $\begin{array}{l}1000 \mathrm{SM} \\
\mathrm{g}\end{array}$ & $\begin{array}{c}\text { Yield } \\
\mathrm{kg} \mathrm{ha}^{-1}\end{array}$ & $\begin{array}{l}\mathrm{DMY} \\
\mathrm{kg} \mathrm{m}^{-3}\end{array}$ & $\begin{array}{l}\mathrm{HI} \\
\% \\
\end{array}$ & $\begin{array}{l}\text { WP } \\
\mathrm{kg} \mathrm{m}^{-3}\end{array}$ \\
\hline \multicolumn{10}{|l|}{ Irrigation level } \\
\hline normal irrigation & $175.2^{\mathrm{a}}$ & $29.8^{\mathrm{a}}$ & $26.4^{\mathrm{a}}$ & $16.9^{\mathrm{a}}$ & $29.4^{\mathrm{a}}$ & $5847.2^{\mathrm{a}}$ & $27874.1^{\mathrm{a}}$ & $23.2^{\mathrm{a}}$ & $0.65^{\mathrm{a}}$ \\
\hline mild deficit irrigation & $152.0^{\mathrm{b}}$ & $27.6^{\mathrm{ab}}$ & $24.5^{\mathrm{b}}$ & $14.0^{\mathrm{a}}$ & $28.5^{\mathrm{ab}}$ & $4026.4^{\mathrm{b}}$ & $22260.9^{b}$ & $21.3^{\mathrm{b}}$ & $0.58^{\mathrm{b}}$ \\
\hline severe deficit irrigation & $138.7^{\mathrm{c}}$ & $25.3^{\mathrm{b}}$ & $23.6^{c}$ & $14.6^{\mathrm{a}}$ & $26.5^{\mathrm{b}}$ & $2759.2^{c}$ & $21480.3^{\mathrm{b}}$ & $16.5^{\mathrm{c}}$ & $0.43^{\mathrm{c}}$ \\
\hline \multicolumn{10}{|l|}{ Genotype } \\
\hline MGS2 & $105.3^{\mathrm{g}}$ & $30.7^{c}$ & $25.9^{c}$ & $12.8^{\mathrm{bc}}$ & $2.9^{\mathrm{f}}$ & $2910.1^{\mathrm{f}}$ & $16188.9^{\mathrm{e}}$ & $17.7^{\mathrm{e}}$ & $0.37^{\mathrm{e}}$ \\
\hline KGS23 & $94.0^{\mathrm{h}}$ & $18.9^{c}$ & $24.0^{\mathrm{d}}$ & $10.9^{\mathrm{bc}}$ & $4.7^{\mathrm{bc}}$ & $4683^{\mathrm{bc}}$ & $16466.6^{\mathrm{e}}$ & $29.2^{\mathrm{b}}$ & $0.63^{\mathrm{b}}$ \\
\hline TN-04-78 & $120.0^{\mathrm{f}}$ & $24.0^{\mathrm{d}}$ & $30.1^{\mathrm{b}}$ & $16.7^{\mathrm{b}}$ & $3.5^{\mathrm{e}}$ & $3491.1^{\mathrm{e}}$ & $24276.2^{\mathrm{c}}$ & $14.4^{\mathrm{e}}$ & $0.45^{\mathrm{d}}$ \\
\hline TN-04-79 & $221.1^{\mathrm{a}}$ & $10.0^{\mathrm{g}}$ & $24.9^{\mathrm{cd}}$ & $15.2^{\mathrm{bc}}$ & $6.5^{\mathrm{a}}$ & $6517.6^{\mathrm{a}}$ & $30906.7^{\mathrm{b}}$ & $21.3^{\mathrm{c}}$ & $0.88^{\mathrm{a}}$ \\
\hline TN-04-129 & $91.9^{\mathrm{h}}$ & $22.3^{\mathrm{d}}$ & $33.4^{\mathrm{a}}$ & $13.4^{\mathrm{bc}}$ & $4.3^{\mathrm{c}}$ & $4304.2^{\mathrm{cd}}$ & $20498.8^{\mathrm{d}}$ & $20.8^{\mathrm{d}}$ & $0.57^{\mathrm{c}}$ \\
\hline TN-04-134 & $201.6^{\mathrm{b}}$ & $14.6^{\mathrm{f}}$ & $21.5^{\mathrm{e}}$ & $22.7^{\mathrm{a}}$ & $6.2^{\mathrm{b}}$ & $4974.3^{\mathrm{b}}$ & $28825.6^{\mathrm{b}}$ & $16.7^{\mathrm{e}}$ & $0.64^{\mathrm{b}}$ \\
\hline TN-04-142 & $227.0^{\mathrm{a}}$ & $7.7^{\mathrm{g}}$ & $21.7^{\mathrm{e}}$ & $28.4^{\mathrm{a}}$ & $1.6^{\mathrm{g}}$ & $1558.7^{\mathrm{g}}$ & $48770.0^{\mathrm{a}}$ & $3.2^{\mathrm{f}}$ & $0.19^{\mathrm{f}}$ \\
\hline TN-04-59 & $159.3^{\mathrm{d}}$ & $53.4^{\mathrm{a}}$ & $24.5^{\mathrm{cd}}$ & $10.4^{\mathrm{bc}}$ & $5.0^{\mathrm{b}}$ & $5047.8^{\mathrm{b}}$ & $18799.6^{\mathrm{de}}$ & $26.8^{\mathrm{b}}$ & $0.67^{\mathrm{b}}$ \\
\hline TN-04-86 & $151.2^{\mathrm{e}}$ & $40.9^{\mathrm{b}}$ & $21.2^{\mathrm{e}}$ & $9.8^{c}$ & $4.7^{\mathrm{bc}}$ & $4685.4^{\mathrm{bc}}$ & $15641.6^{\mathrm{e}}$ & $30.3^{\mathrm{a}}$ & $0.63^{\mathrm{b}}$ \\
\hline TN-04-90 & $180.6^{\mathrm{c}}$ & $53.2^{\mathrm{a}}$ & $21.1^{\mathrm{e}}$ & $11.4^{\mathrm{bc}}$ & $3.9^{\mathrm{d}}$ & $3937.2^{\mathrm{d}}$ & $18343.6^{\text {de }}$ & $22.6^{\mathrm{c}}$ & $0.538^{\mathrm{c}}$ \\
\hline
\end{tabular}

PH: plant height; PL: panicle length; SD: stem diameter; NoL: number of leaves; 1000 SM: 1000 seed mass; DMY: dry matter yield; HI: harvest index; WP: water productivity.

Means followed by the same letter in a column do not differ by Duncan's test at $5 \%$ probability 
The average $\mathrm{PH}$ reduced $13.2 \%$ and $20.8 \%$ under mild and severe deficit irrigation, respectively (Table 3 ). The reduction ratios for PL were $7 \%$ and $15 \%$ under mild and severe deficit irrigation, respectively (Table 3 ). Ashraf and Foolad (2007) indicated a reduction in turgidity and cell growth and development under water shortage observed as a reduction in $\mathrm{PH}$ or panicle size. A significant effect of drought stress on the $\mathrm{PH}$ of forage sorghum has also been demonstrated (Mutava et al., 2011).

Stem diameter (SD) decreased $7.2 \%$ and $10.6 \%$ under mild and severe stress, respectively (Table 3). Our results were in line with Almodares et al. (2013) demonstrating that the stem diameter of sorghum decreased proportionally to water deficit intensity. The reduction of SD in sugarcane under water deficit has been proven (Silva et al., 2008). Controversial results were reported by other studies pointing out no reduction in SD under drought stress (Almodares et al., 2013; Fracasso et al., 2016; Ottman et al., 2001). The 1000 SM reduction was $9.8 \%$ from normal irrigation to severe deficit irrigation (Table 3). Deficit irrigation resulted in a notable fall in DMY equal to $79.9 \%$ and $77.1 \%$ under mild and severe stress, respectively (Table 3 ).

Genotypes TN-04-79 and TN-04-142 exhibited the highest $\mathrm{PH}$ value and genotypes KGS23 and TN-04-129 were the lowest in PH (Table 3). Generally, taller sorghum genotypes are favored for small-scale farms that mechanical harvests are not employed (Devnarain et al., 2016). Genotypes TN-04-90 and TN-04-59 had the highest PL and genotypes TN-04-79 and TN-04-142 ranked the last (Table 3). Different values of SD were obtained with the highest value for the genotype TN-04-129 (Table 3). The highest NoL belonged to TN-04-134 and TN04-142. Genotypes TN-04-79 and TN-04-90 ranked the highest and the lowest 1000 SM, respectively (Table 3). The genotype TN-04-142 produced the highest DMY. There were no significant differences between MGS2, KGS23, TN-04-59, TN-04-86, and TN-04-90 in DMY as the lowest rank (Table 3).

\subsection{GRAIN YIELD, HARVEST INDEX, AND WA- TER PRODUCTIVITY (WP)}

The effects of deficit irrigation, genotype, and their interaction on yield, HI, and WP were significant $(p<$ $0.01)$. Grain yield and HI decreased significantly in response to water deficit, resulting in lower values equal to $52.8 \%$ and $28.9 \%$, respectively (Table 3 ). The mean of WP under severe deficit irrigation was reduced by $31.7 \%$ compared to normal irrigation (Table 3). Chimonyo et al. (2016) reported no significant reduction in sorghum yield under deficit irrigation in comparison to full irrigation (3160 kg ha-1 vs. $3240 \mathrm{~kg} \mathrm{ha}^{-1}$ ), indicating sorghum as drought tolerant, which is suitable for marginal lands. However, our results noted that sub-optimal irrigation resulted in sub-optimal WP. Hence, an important point to farmers is the benefit of irrigating sorghum considering the water supply.

The highest grain yield and WP under normal irrigation belonged to genotype TN-04-79 followed by TN04-134 (Fig. 2). Under mild deficit irrigation, genotype TN-04-79 had the highest grain yield and WP, because WP of this genotype under mild deficit irrigation was slightly higher (not statistically significant) than that value under normal irrigation. The highest values of grain yield and WP, when severe deficit irrigation was imposed, were related to genotype KGS23 followed by TN04-79 and TN-04-86. Moreover, the highest WP obtained for genotype TN-04-79 under mild deficit irrigation and the lowest value of WP belonged to genotype TN-04-142 under severe stress (Fig. 2).

It has been reported that sorghum WP was in a range of $1.24-1.34 \mathrm{~kg} \mathrm{~m}^{-3}$ in Nebraska under normal irrigation (Maman et al. 2003). Grain WP in the trial of Hadebe et al. (2020) was relatively lower in a range of $0.75-1.1 \mathrm{~kg} \mathrm{~m}^{-3}$ for three different genotypes. Moreover, they attributed high WP under irrigation to high yield proportional to water applied in the field. The effect of genotype, duration, and extent of water stress may account for the variation of results in this study with those of other studies.

\subsection{VALUES AND RANKS OF DROUGHT INDICES}

Mean comparison of ranking values (R), ranking mean values (R') and rank sum (RS) under mild deficit irrigation showed that genotype TN-04-79 performed superiorly except for TOL (ranked 3) (Table 5). The superior genotype based on the TOL index was genotype TN-04-129. On the other hand, genotype TN-04-142 performed inferiorly based on $\mathrm{Y}_{\mathrm{p}}, \mathrm{Y}_{\mathrm{s}}$, and all drought tolerance indices except for TOL ranked 8 (Table 5). A different trend in the response of the genotypes to severe deficit irrigation was observed. While genotype TN-0479 performed superiorly based on $Y_{p}$, MP, STI, GMP, and HM, genotype KGS23 was superior when considering $Y_{s}$, TOL, SSI, YSI, YRR, and YI indices (Table 5).

It could be concluded that different drought-tolerance indices presented herein introduced different genotypes as drought tolerant. Similar results have been reported for the screening of drought-tolerant genotypes based on various indices (Nikneshan et al., 2019; Abd ElMohsen et al. 2015). Therefore, the selection of tolerant 

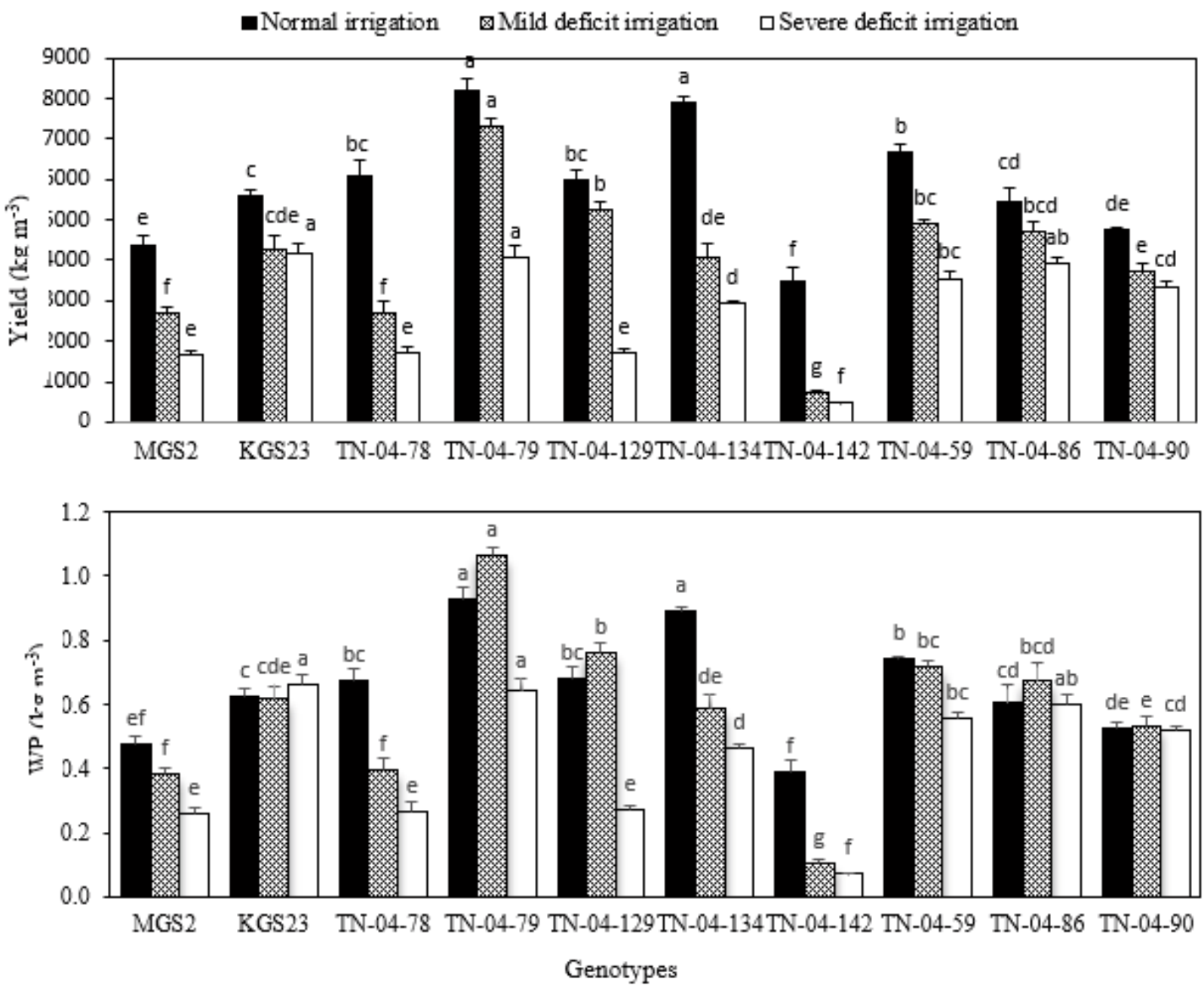

Figure 2: Grain yield and water productivity (WP) of 10 grain sorghum genotypes under normal irrigation, mild and severe deficit irrigation. Means followed by the same letter are not significantly different in each level of irrigation treatment (Duncan's test, $p$ $<0.05)$

genotypes was adopted by the ranking method based on ranking mean values (R'), standard deviation of ranks (SDR), and rank sum (RS).

According to values of R' and RS calculated based on the yield under normal irrigation and mild deficit irrigation, genotype TN-04-79 exhibited the first mean rank value and sum rank value followed by genotype TN04-129 indicating that these genotypes can be primarily categorized as the most tolerant to mild deficit irrigation. Whilst, genotype TN-04-142, MGS2, and TN-04-78 exhibited the worst mean rank and rank sum, respectively, that can be considered as the most susceptible to mild water deficit irrigation (Table 5). On the other hand, R' and RS calculated based on yield in normal irrigation and severe deficit irrigation presented different results. The first mean rank and sum rank value belonged to gen- otype KGS23, while genotype TN-04-142 was inferior in R' and RS (Table 5).

\subsection{CORRELATIONS AMONG DROUGHT INDI- CES}

Pearson's correlation coefficients ( $r$ ) between $\mathrm{Y}_{\mathrm{p}}, \mathrm{Y}_{\mathrm{s}}$, and the indices were determined to select the best indices for the screening of drought-tolerant genotypes (Fig. 3). A positive significant correlation between $\mathrm{Y}_{\mathrm{p}}$ and $\mathrm{Y}_{\mathrm{s}} \mathrm{un}$ der mild and severe deficit irrigation was recorded (Fig. 3). This may imply that high yielding potential under normal irrigation is necessarily accompanied by reasonable yield under mild and severe deficit irrigation. Similar 


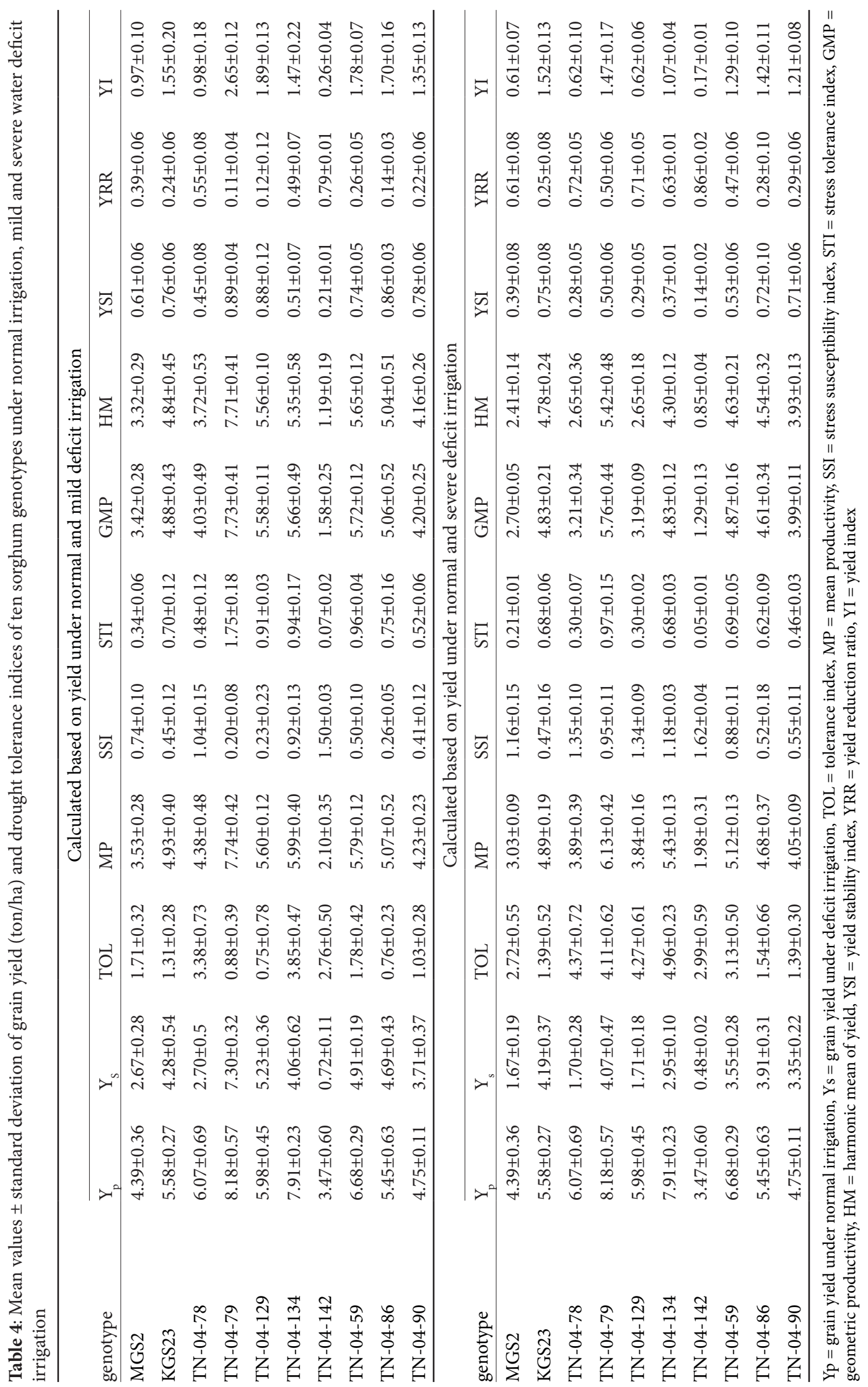




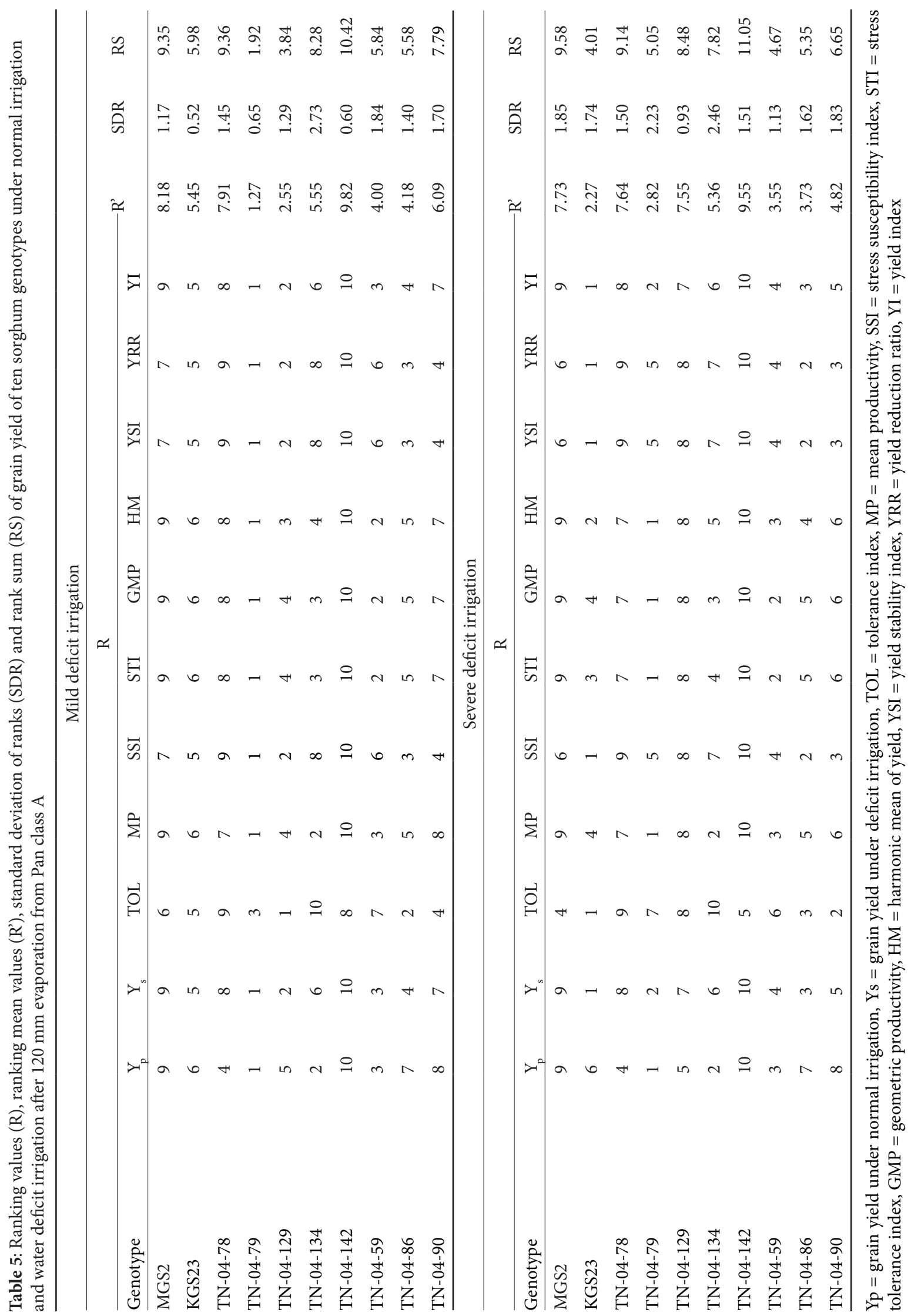



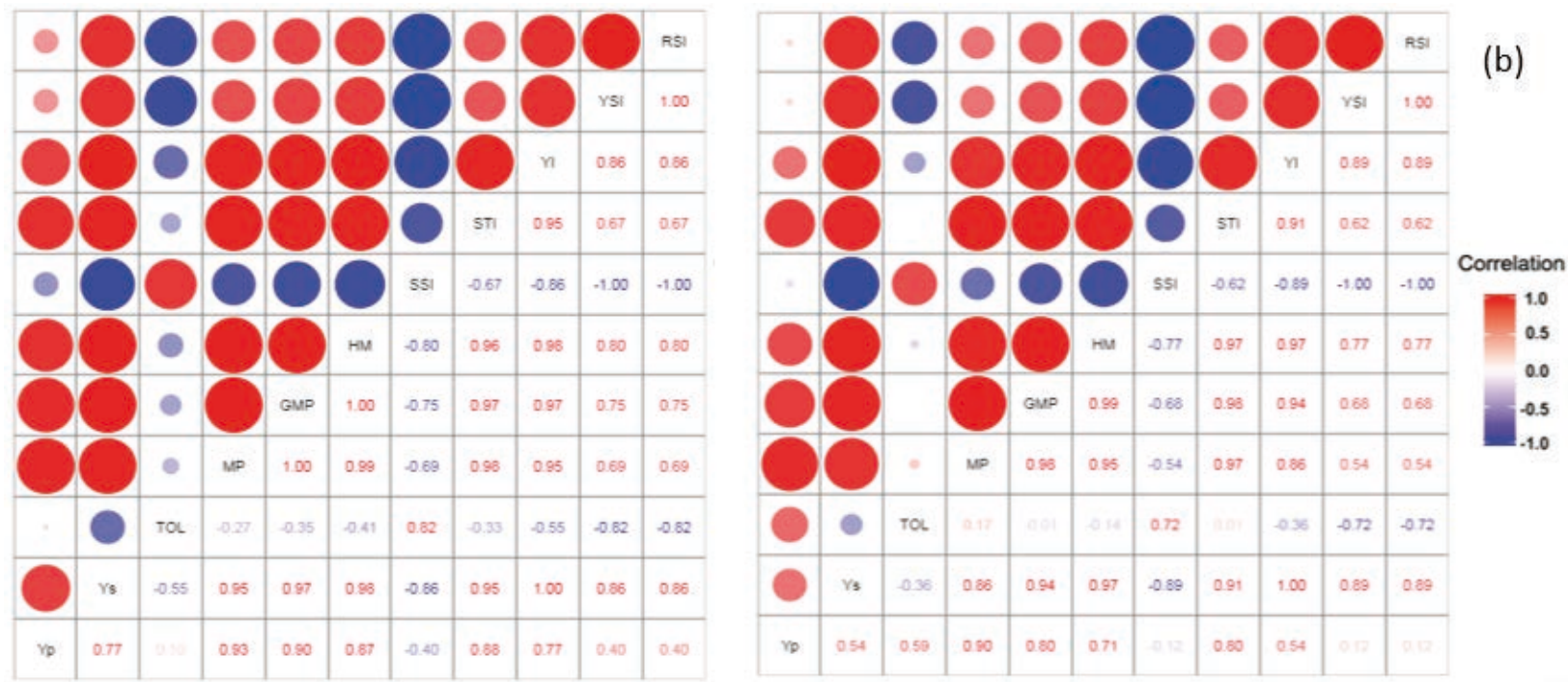

Fig. 3: Heat map based on the actual values of indices (Pearson's correlation analysis) across 10 sorghum genotypes produced using iPASTIC online tool kit. $Y_{p}$, yield under normal irrigation; $Y_{s}$, yield under mild deficit irrigation for (a) and under severe deficit irrigation for (b); TOL, tolerance index; MP, mean productivity, GMP, geometric mean probability; HM, Harmonic mean; SSI, stress susceptibility index; STI, stress tolerance index; YI, yield index; YSI, yield stability index; RSI, relative stress index

results of the wheat response to drought were previously recorded by Abebe et al. (2020).

While there was a significant correlation between $\mathrm{Y}_{\mathrm{s}}$ (mild and severe deficit irrigation) and all the indices, there was no correlation between $Y_{p}$ and SSI, YSI, and YRR. There was no correlation between $\mathrm{Y}_{\mathrm{p}}$ and TOL under mild deficit irrigation. On the other hand, a positive significant correlation was obtained between $\mathrm{Y}_{\mathrm{p}}$ and TOL calculated based on yield in severe deficit irrigation suggesting that selection based on the low score of TOL may lead to enhanced yield under severe deficit irrigation but reduced yield under normal irrigation (Fig. 3). Also, yield in all irrigation treatments was significantly and positively correlated with MP, STI, GMP, HM, and YI (Fig. 3). Thus, it can be concluded that these indices were more efficient in the selection of genotypes with high yield potential under different water conditions.

Indices being significantly correlated with grain yield under both normal irrigation and water deficit irrigation are suitable for the screening of genotypes (Mitra, 2001). Therefore, indices MP, STI, GMP, HM, and YI which were positively correlated with both $\mathrm{Y}_{\mathrm{p}}$ and $\mathrm{Y}_{\mathrm{s}}$ at $p$ $\leq 0.01$ (Fig. 3) may be considered as better predictors of yield in different irrigation. As well, sorghum genotypes with high values of MP, STI, GMP, HM, and YI can be thus regarded as drought tolerant. Our results are somewhat in agreement with those findings of Nouri et al. (2011) and Golabadi et al. (2006) who found a correlation between either $\mathrm{Y}_{\mathrm{s}}$ or $\mathrm{Y}_{\mathrm{p}}$ and MP, GMP, and STI.

A perfect positive correlation $(r=1)$ was noted be- tween $Y_{s}$ and $Y I$ and between SSI and YRR. On the other hand, a perfect negative correlation $(\mathrm{r}=-1)$ was noted between SSI and YSI, YSI, and YRR in both mild and severe water deficit irrigation (Fig. 3). A similar finding was recorded by Mickky et al. (2019) who evaluated 10 wheat cultivars based on drought tolerance indices under normal irrigation $\left(\mathrm{Y}_{\mathrm{p}}\right)$ and deficit irrigation $\left(\mathrm{Y}_{\mathrm{s}}\right)$.

\subsection{CLUSTER ANALYSIS}

Classification of genotypes according to $\mathrm{Y}_{\mathrm{p}}, \mathrm{Y}_{\mathrm{s}}$, and various indices under normal irrigation and mild deficit irrigation categorized 10 sorghum into three groups; group 1 including MGS2, TN-04-90, TN-04-78 and TN04-14; group 2 including KGS23, TN-04-86, TN-04-12, TN-04-99 and TN-04-13; and group 3 including genotype TN-04-79 (Fig. 4a). Clustering based on yield and drought tolerance indices under normal irrigation and mild deficit irrigation grouped the genotypes into tolerant, semi-tolerant/susceptible, and susceptible. The first group with the lowest value of R' and RS (TN-04-79) can be distinguished as tolerant to mild deficit irrigation. The second group had mean values of R' (2.75-5.67) and RS (3.97-8.44) considered as semi-sensitive/tolerant and the third group with higher R' and RS was the most susceptible genotypes to mild deficit irrigation (Fig. 4 a). 

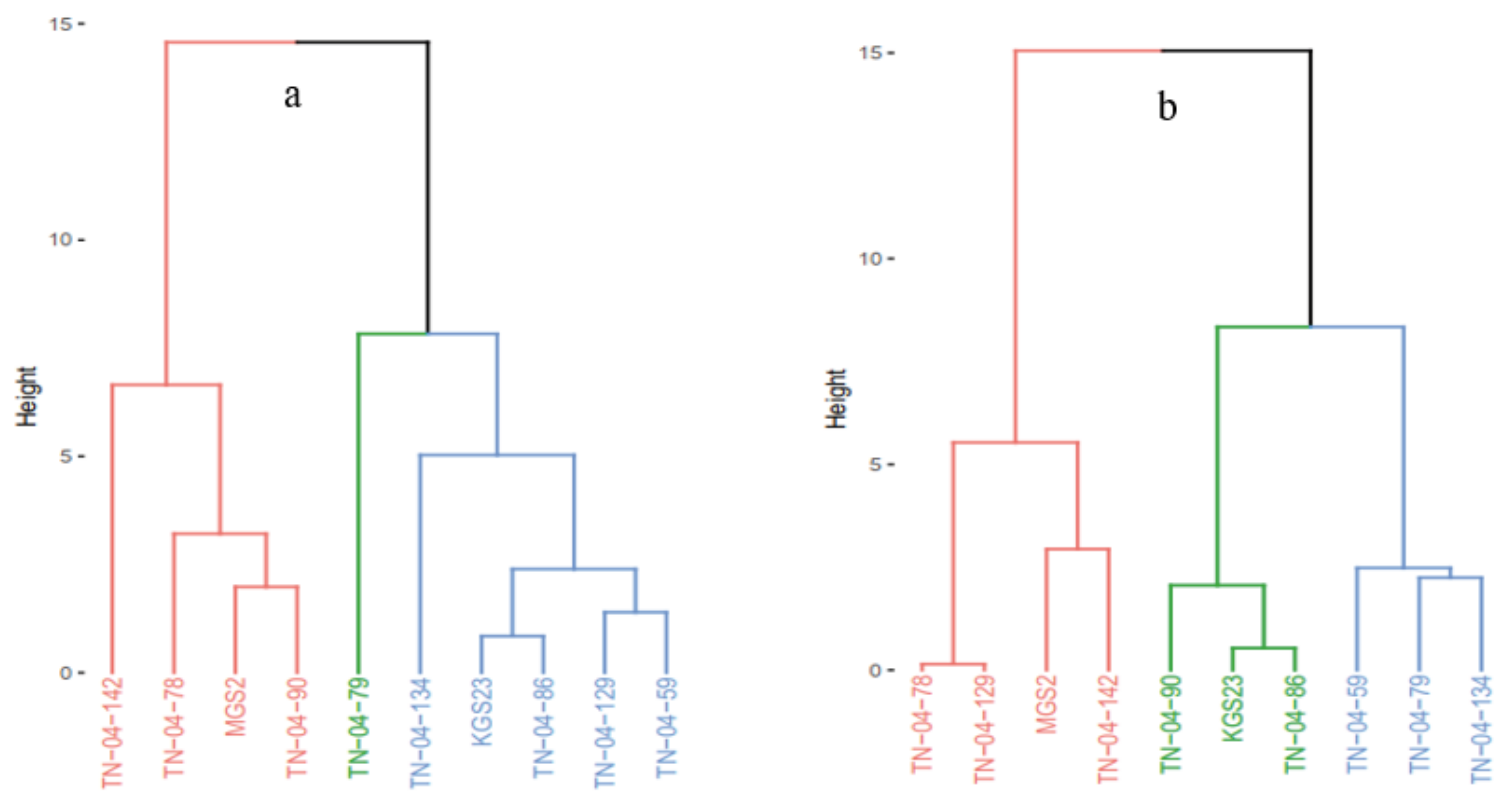

Fig. 4: Dendrograms of the cluster analysis and similarity coefficients among 10 sorghum genotypes based on $\mathrm{Y}_{\mathrm{p}}$, $\mathrm{Y}_{\mathrm{s}}$, and the drought tolerance indices under normal irrigation and mild deficit irrigation (a) and under normal irrigation and severe deficit irrigation (b)

On the other hand, three different clusters were observed based on $Y_{p}, Y_{s}$, and drought tolerance indices under normal irrigation and severe deficit irrigation (Fig. 4b). Genotypes MGS2, TN-04-14, TN-04-78, and TN04-12 were classified into group 1; KGS23, TN-04-86, and TN-04-90 into group 2; and TN-04-79, TN-04-13, and TN-04-59 into group 3. The first and second groups included the genotypes with the lowest to medium values of R' and RS and thus were considered to be tolerant or semi-tolerant. The genotypes of the third group had the highest values of R' and RS indicating the most susceptible to severe deficit irrigation. Cluster analysis has been extensively employed for the determination of genetic diversity and classification of genotypes under various abiotic stresses (Golabadi et al. 2006; Mohammadi et al. 2011).

\subsection{PRINCIPAL COMPONENT ANALYSIS (PCA) AND BIPLOT}

The PCA results revealed that the first two principal components accounted for $98.51 \%$ (PC1:81.03 \%, PC2:4.63 \%) of the total variation in yield performance and nine yield-based indices calculated under normal irrigation and mild deficit irrigation. Biplot showed that the $\mathrm{PC}_{1}$ was positively correlated with yield $\left(\mathrm{Y}_{\mathrm{p}}\right.$ and $\mathrm{Y}_{\mathrm{s}}$ under mild stress) and all indices except TOL and SSI, whereas $\mathrm{PC}_{2}$ was positively correlated with yield $\left(\mathrm{Y}_{\mathrm{p}}\right.$ and
$\mathrm{Y}_{\mathrm{s}}$ under mild deficit irrigation) and all indices excluding RSI and YSI (Fig. 5a).

On the other hand, the PCA biplot for yield ( $\mathrm{Y}_{\mathrm{p}}$ and $\mathrm{Y}_{\mathrm{s}}$ under severe deficit irrigation) and drought tolerance indices of sorghum genotypes was reflecting $99.28 \%$ $\left(\mathrm{PC}_{1}: 74.6 \%, \mathrm{PC}_{2}: 24.63 \%\right)$ of the total variability in data (Fig. 5b). The biplot categorized the indices into three groups (Fig. 5). The first group was those with high $\mathrm{PC}_{1}$ and $\mathrm{PC}_{2}\left(\mathrm{Y}_{\mathrm{p}}, \mathrm{MP}\right.$, STI, GMP, HM, YI, and $\mathrm{Y}_{\mathrm{S}}$ in Fig. $5 \mathrm{a}$ and $\mathrm{Y}_{\mathrm{p}}, \mathrm{MP}$, STI, GMP, and HM in Fig $5 \mathrm{~b}$ ). The second group was indices with low $\mathrm{PC}_{1}$ but high $\mathrm{PC}_{2}$ (SSI and TOL) (Fig. 5a,b) and the third group were those with high $\mathrm{PC}_{1}$ but low $\mathrm{PC}_{2}$ including RSI (Fig. 5a,b) and $\mathrm{Y}_{\mathrm{s}}$ and YI (Fig. $5 b)$.

The cosine of the angle between the vectors of any two indices in a biplot is an indicator of the correlation coefficient. Therefore, we can note that those indices whose vector has been placed between the vectors of $Y_{p}$ and $\mathrm{Y}_{\mathrm{s}}$ are appropriate for the selection of drought-tolerant genotypes. It can be implied that MP, GMP, STI, HM, and $\mathrm{YI}$ allocating between $\mathrm{Y}_{\mathrm{p}}$ and $\mathrm{Y}_{\mathrm{s}}$ are the best indices to distinguish tolerant from susceptible genotypes. Herein, the results obtained from PCA (Fig. 5) confirmed those obtained from correlation coefficients (Fig. 3).

The results of our study showed that TN-04-79 and TN-04-59 are tolerant genotypes with the highest values for the MP, GMP, STI, and HM indices, while genotypes KGS23, TN-04-129, TN-04-86, and TN-04-90 under mild stress and genotypes KGS23, TN-04-86, TN-04-90 with the highest values for YSI and RSI were the most 

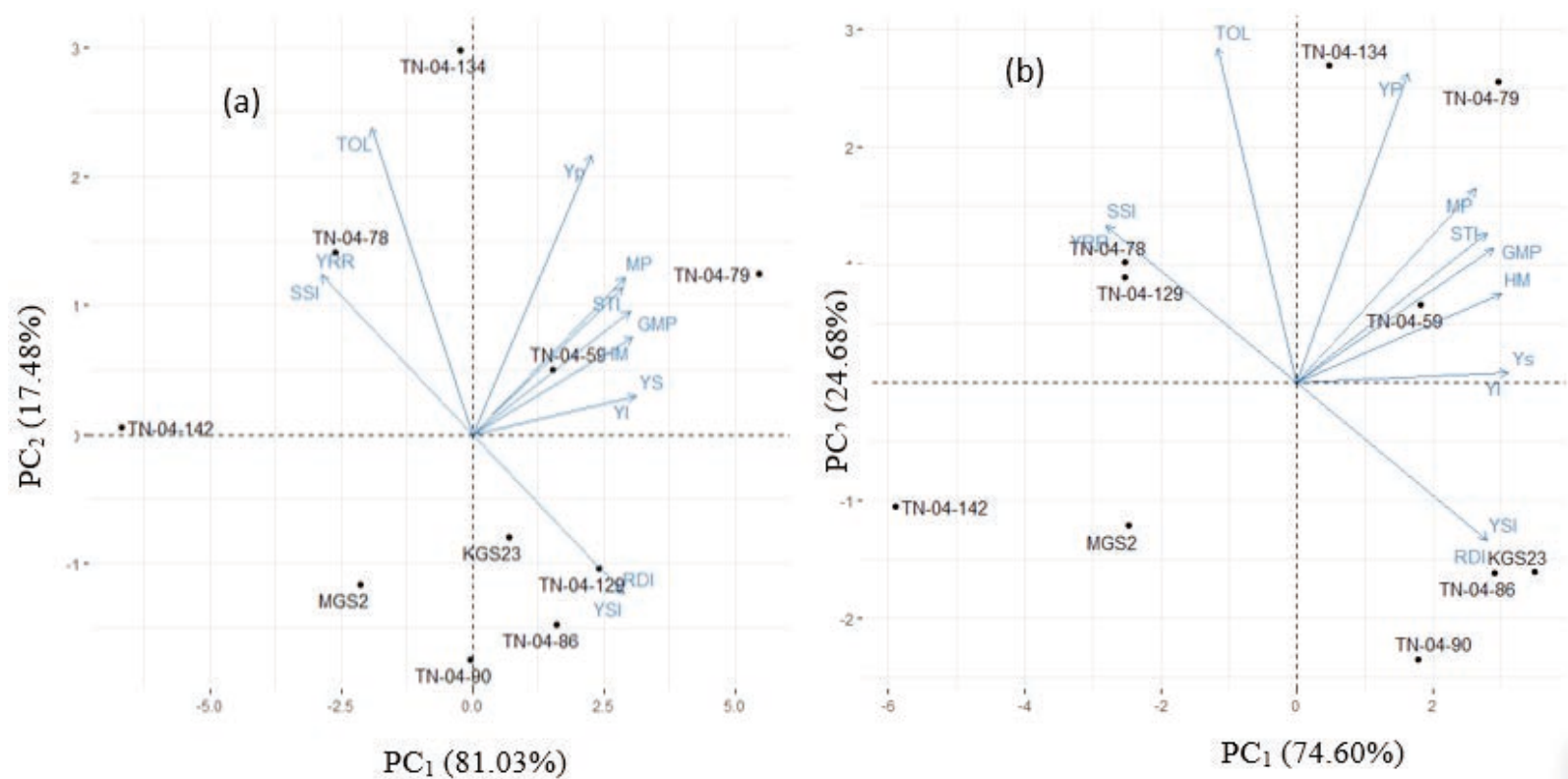

Fig. 5: Principal components (PC) analysis based on the correlation matrix of yield under normal irrigation ( $\left.\mathrm{Y}_{\mathrm{p}}\right)$ and yield under mild deficit irrigation (a) and severe deficit irrigation $(\mathrm{b})\left(\mathrm{Y}_{\mathrm{s}}\right)$ and nine tolerance and susceptibility indices calculated using iPASTIC online tool kit. $Y_{p}$, yield under normal irrigation; $Y_{s}$, yield under mild deficit irrigation for (a) and under severe deficit irrigation for (b); TOL, tolerance index; MP, mean productivity, GMP, geometric mean probability; HM, Harmonic mean; SSI, stress susceptibility index; STI, stress tolerance index; YI, yield index; YSI, yield stability index; RSI, relative stress index.

stable genotypes (Table 4). Introduction of these tolerant genotypes into the sorghum breeding programs may be suggested to policymakers to release new cultivars tolerant to drought stress. It has been noted that increasing harvest index can improve yield stability (Kashiwagi et al., 2015). The reduction of grain yield under deficit irrigation could lead to a lower harvest index. We also found that indices including MP, GMP, HM, STI, YI, and YSI are strongly correlated with sorghum yield. Thus, these drought-tolerant indices should benefit the breeders in breeding programs.

\section{CONCLUSIONS}

In the current study, eight sorghum genotypes collected from different parts of Iran along with two promising lines reported as drought-tolerant were compared in terms of response to deficit irrigation. The grain yield and water productivity of the genotypes were significantly influenced by water deficit irrigation. The relative efficacy of selection indices could be an advantage using two or more traits simultaneously than using single traits independently. Thus, indices including MP, STI, GMP, $\mathrm{HM}$, and $\mathrm{YI}$, highly correlated with $\mathrm{Y}_{\mathrm{p}}$ and $\mathrm{Y}_{\mathrm{s}}$, may be more suitable for the selection of drought-tolerant genotypes. Screening of tolerant genotypes to water deficit irrigation using the ranking method and cluster analysis discriminated genotypes as the most tolerant, semi-tolerant/sensitive, and susceptible. Therefore they are recommended to be used in breeding programs as parents for improvement of drought tolerance in commercial cultivars. Further evaluation of these genotypes based on drought indices across multiple locations and years is still demanded to validate their stability for developing sorghum cultivars.

\section{ACKNOWLEDGMENTS}

The present work was supported by Agricultural Organization of Fars [Project number 24-50-03-332961709].

\section{ABBREVIATIONS}

ANOVA: Analysis of variance; PCA: principal component analysis; $\mathrm{PH}$ : plant height; PL: panicle length; SD: stem diameter; NoL: number of leaves per plant; 1000 SM: 1000 seed mass; DMY: dry matter yield; HI: harvest index; WP: Water productivity; $\mathrm{Y}_{\mathrm{p}}$ : grain yield under normal irrigation; $\mathrm{Y}_{\mathrm{s}}$ : grain yield under deficit irrigation; MP: mean productivity; TOL: tolerance index; SSI: stress susceptibility index; STI: stress tolerance index; GMP: geometric productivity; HM: harmonic mean of yield; 
YSI: yield stability index; YRR: yield reduction ratio; YI: yield index.

\section{REFERENCES}

Abd El-Mohsen, A. A., Abd El-Shafi, M. A., Gheith, E. M. S., Suleiman, H. S. (2015). Using different statistical procedures for evaluating drought tolerance indices of bread wheat genotypes. Advance in Agriculture and Biology, 4, 1930. https://doi.org/10.15192/PSCP.AAB.2015.4.1.1930

Abebe, T., Belay, G., Tadesse, T., Keneni, G. (2020). Selection efficiency of yield based drought tolerance indices to identify superior sorghum [Sorghum bicolor (L.) Moench] genotypes under two-contrasting environments. African Journal of Agricultural Research, 15(3), 379-392. https://doi. org/10.5897/AJAR2020.14699

Ali, M. H., Talukder, M. S. U. (2008). Increasing water productivity in crop production: a synthesis. Agricultural Water Management, 95, 1201-1213. https://doi.org/10.1016/j.agwat.2008.06.008

Almodares, A., Hotjatabady, R. H., Mirniam, E. (2013). Effects of drought stress on biomass and carbohydrate contents of two sweet sorghum cultivars. Journal of Environmental Biology, 34, 585-589.

Anwar, H. A., Perveen, R., Mansha, M., Abid, M., Sarwar, Z. M., Aatif, H. M., Umar, U., Sajid, M., Aslam, H. M. U., Alam, M. M., Rizwan, M., Ikram, R. M., Alghanem, S. M. S., Rashid, A., Khan, K. A. (2020). Assessment of grain yield indices in response to drought stress in wheat (Triticum aestivum L.). Saudi Journal of Biological Sciences, 27(7), 1818-1823. https://doi.org/10.1016/j.sjbs.2019.12.009

Ashraf, M., Foolad, M. R. (2007). Roles of glycine, betaine and proline in improving plant abiotic stress resistance. Environmental and Experimental Botany, 59, 206-216. https:// doi.org/10.1016/j.envexpbot.2005.12.006

Blum, A. 1988. Plant breeding for stress environments. CRC Press, Boca Raton, Florida, USA. Rosielle A. A., Hamblin J. (1981). Theoretical aspects of selection for yield in stress and non-stress environments. Crop Science, 21, 943-946. https://doi.org/10.2135/cropsci1981.0011183X002100060 $033 \mathrm{x}$

Bouslama, M., Schapaugh, W. T. (1984). Stress tolerance in soybean. Part 1: evaluation of three screening techniques for heat and drought tolerance. Crop Science, 24, 933-937. https://doi.org/10.2135/cropsci1984.0011183X002400050 026x

Chimonyo, V. G. P., Modi, A. T., Mabhaudhi, T. (2016). Water use and productivity of a sorghum-cowpea-bottle gourd intercrop system. Agricultural Water Management, 165, 8296. https://doi.org/10.1016/j.agwat.2015.11.014

Clarke, D., Smith, M., El-Askari, K. (2001). CropWat for Windows: User Guide; University of Southampton: Southampton, UK.

Clarke, J. M., DePauw, R. M., Townley Smith, T. F. (1992). Evaluation of methods for quantification of drought tolerance in wheat. Crop Science, 32, 423-428. https://doi.org/10.2135/cr opsci1992.0011183X003200030029x
Devnarain, N., Crampton, B. G., Chikwamba, R., Becker, J. V. W., \& O'Kennedy, M. M. (2016). Physiological responses of selected African sorghum landraces to progressive water stress and re-watering. South African Journal of Botany, 103, 61-9. https://doi.org/10.1016/j.sajb.2015.09.008

Doorenbos, J., Kassam, A. H. (1986). Yield Response to Water, Irrigation and Drainage Paper 33. Food and Agricultural Organization of the United Nations: Rome.

Doorenbos, J., Pruitt, W. O. (1977). Crop water requirements. Revised 1977. FAO Irrig Drain. Paper 24. FAO of the United Nations, Rome, pp 144.

Fernandez, G. C. J. (1992). Effective selection criteria for assessing plant stress tolerance. In: Proceedings of the International Symposium on Adaptation of Vegetables and other Food Crops in Temperature and Water Stress, Taiwan 13-16 August 1992, 257-270 p.

Fischer, R. A., Maurer, R. (1978). Drought resistance in spring wheat cultivars. I. Grain yield responses. Australian Journal of Agricultural Research, 29, 897-912. https://doi. org/10.1071/AR9780897

Fracasso, A., Trindade, L., Amaducci, S. (2016). Drought tolerance strategies highlighted by two Sorghum bicolor races in a dry-down experiment. Journal of Plant Physiology, 190, 1-14. https://doi.org/10.1016/j.jplph.2015.10.009

Gavuzzi, P., Rizza, F., Palumbo, M., Campaline, R. G., Ricciardi, G. L., Borghi, B. (1997). Evaluation of field and laboratory predictors of drought and heat tolerance in winter cereals. Canadian Journal of Plant Science, 77, 523-531. https://doi. org/10.4141/P96-130

Golabadi, M. A., Arzani, S. A., Maibody, M. (2006). Assessment of drought tolerance in segregating populations in durum wheat. African Journal of Agricultural Research, 1(5), 62171.

Golestani Araghi, S., Assad, M. T. (1998). Evaluation of four Screening Techniques for Drought Resistance and Their Relationship to Yield Reduction Ratio in Wheat. Euphytica. 103, 293-299. https://doi.org/10.1023/A:1018307111569

Hadebe, S. T., Mabhaudhi, T., Modi, A. T. (2020). Water productivity of selected Sorghum genotypes under rainfed conditions. International Journal of Plant Production, 14, 259272. https://doi.org/10.1007/s42106-019-00082-4

Jafari, A., Paknejad, F., Jami Al-Ahmadi, M. (2009). Evaluation of selection indices for drought tolerance of corn (Zea mays L.) hybrids. International Journal of Plant Production, 3(4), 33-38. https://doi.org/10.22069/IJPP.2012.661

Kashiwagi, J., Krishnamurthy, L., Purushothaman, R., Upadhyaya, H. D., Gaur, P. M., Gowda, C. L. L., et al. (2015). Scope for improvement of yield under drought through the root traits in chickpea (Cicer arietinum L.). Field Crop Research, 170, 47-54. https://doi.org/10.1016/j.fcr.2014.10.003

Khalili, M., Pour-Aboughadareh, A., Naghavi, M. R., MohammadAmini, E. (2014). Evaluation of drought tolerance in safflower genotypes based on drought tolerance indices. Notulae Botanicae Horti Agrobotanici Cluj-Napoca, 42, 214 218. https://doi.org/10.15835/nbha4219331

Ludlow, M. M., Muchow, R. C. A Critical Evaluation of Traits for Improving Crop Yields in Water-Limited Environments1. In: Brady N. C., editor. Advances in Agronomy. Vol. 43. Academic Press; Cambridge, MA, USA: 1990. pp. 
107-153. https://doi.org/10.1016/S0065-2113(08)60477-0

Maman, N., Lyon, D. J., Mason, S. C., Galusha, T. D., Higgins, R. (2003). Pearl millet and grain sorghum yield response to water supply in Nebraska. Agronomy Journal, 95, 16181624. https://doi.org/10.2134/agronj2003.1618

Mickky, B., Aldesuquy, H., Elnajar, M. (2019). Uni- and multivariate assessment of drought response yield indices in 10 wheat cultivars. Journal of Crop Science and Biotechnology, 22, 21-29. https://doi.org/10.1007/s12892-018-0221-0

Mitra, J. (2001). Genetics and genetic improvement of drought resistance in crop plants. Current Science, 80, 758-762.

Mohammadi, M., Karimizadeh, F., Abdipour, M. (2011). Evaluation of drought tolerance in bread wheat genotypes under dryland and supplemental irrigation conditions. Australian Journal of Crop Science, 5, 487-493.

Mutava, R. N., Prasad, P. V. V., Tuinstra, M. R., Kofoid, M. D., $\mathrm{Yu}, \mathrm{j}$. (2011). Characterization of sorghum genotypes for traits related to drought tolerance. Field Crops Research, 123, 10-18. https://doi.org/10.1016/j.fcr.2011.04.006

Nikneshan, P., Tadayyon, A., Javanmard, M. (2019). Evaluating drought tolerance of castor ecotypes in the center of Iran. Heliyon, 5, e01403. https://doi.org/10.1016/j.heliyon.2019. $\mathrm{e} 01403$

Nouri, A., Etminan, A., Jaime, A., Silva, T. D., Mohammadi, R. (2011). Assessment of yield, yield related traits and drought tolerance of durum wheat genotypes (Triticum turjidum var. durum Desf.). Australian Journal of Crop Science,

\section{$5,8-16$.}

Ottman, M. J., Kimball, B. A., Pinter, P. J. Jr., Wall, G. W., Vanderlip, R. L., Leavitt, S. W., LaMorte, R. L., Matthias, A. D., Brooks, T. J. (2001). Elevated $\mathrm{CO}_{2}$ increases sorghum biomass under drought conditions. New Phytologist, 150, 261273. https://doi.org/10.1046/j.1469-8137.2001.00110.x

Priyanka, V., Kumar, R., Dhaliwal, I., Kaushik, P. (2021). Germplasm conservation: Instrumental in agricultural biodiversity-A review. Sustainability, 13(12), 6743. https://doi. org/10.3390/su13126743

Silva, M. D. A., Silva, J. A. G. D., Enciso, J., Sharma, V., Jifon, J. (2008). Yield components as indicators of drought tolerance of sugarcane. Scientia Agricola, 65, 620-627. https:// doi.org/10.1590/S0103-90162008000600008

Surendran, U., Raja, B. A. P., Kumar, V., Rajan, K., Jayakumar, M. (2019). Analysis of drought from humid, semi-arid and arid regions of India using DrinC model with different drought indices. Water Resources Management, 33, 15211540. https://doi.org/10.1007/s11269-019-2188-5

Tari, I., Laskay, G., Takács, Z., Poór, P. (2013). Response of sorghum to abiotic stresses: A review. Journal of Agronomy and Crop Science, 199, 264-274. https://doi.org/10.1111/ jac. 12017

Zhang, X., Lei, L., Lai, J., Zhao, H., Song, W., (2018). Effects of drought stress and water recovery on physiological responses and gene expression in maize seedlings. BMC Plant Biology, 18, 68. https://doi.org/10.1186/s12870-018-1281-x 